\section{Official controls on food safety: Competent Authority measures}

\author{
Alfredo Rossi, ${ }^{1}$ Giovanni Rossi, ${ }^{2}$ \\ Alfonso Rosamilia, ${ }^{3}$ Massimo Renato \\ Micheli \\ ${ }^{1}$ Local Health Authority of Benevento; \\ ${ }^{2}$ Local Health Authority of Parma; \\ ${ }^{3}$ Local Health Authority of Modena, \\ Italy
}

\section{Abstract \\ Since December $14^{\text {th }}, 2019$, Regulation} (EC) No $882 / 2004$ has been replaced by Regulation (EU) 2017/625, which sets the activity of the official control on food safety, extending the scope of the previous regulation. The broader scope of the new regulation aims to ensure compliance across the European Member States in the Union in the fields of food, feed, animal health and welfare, plant health and plant protection products. The administrative measures that the Competent Authorities adopt following the finding of a non-compliance regarding food hygiene, should be take into account not only the risk assessment, but a series of criteria dictated by both European and national legislation and comply with the generals principles governing administrative action. The aim of this study is to conduct a legal analysis of: (i) the provisions set out in Regulation (EU) 2017/625 concerning executive actions in the case of noncompliance, and (ii) the criteria used to assess the appropriate remedial measures. The study was completed by analysing recent legal cases on food safety, which in many cases have censure the work of the Local Competent Authority, and has brought to light a distorted and uneven application of the legislation on food safety, especially in cases in which drastic measures had been adopted, such as the closure of the productive activities, which has a heavy impact on the food business operators in the food sector concerned. In addition to an incorrect application of the specific health legislation, there is also a violation of the principle of proportionality, of community origin. Indeed, the principle of proportionality, an essential factor in administrative review, which has been used as a leading criterion in the adoption of administrative measures by of the Health Authorities of the Competent Authority.

\section{Introduction}

The European Union (EU), in redesigning the system of official controls to guarantee the application of the legislation on the agri-food supply chain, leaves the Member States the faculty to apply the specific regulations and to organize the controls in order to verify compliance with the relevant provisions by operators in the sector at all stages of production, processing and distribution. The Regulation (EU) 2017/625, which from December 14 ${ }^{\text {th }}, 2019$ will replace Regulation (EC) No 882/2004 with the aim of harmonizing, unifying and rationalizing the regulatory framework of the entire agri-food chain, widens the field of application to the following sectors: plant health, trade and use of protected plant products, organic production, use and labeling of Protected Designations of Origin (PDOs) or Protected Geographical Indications (PGIs) - Traditional Speciality Guaranteed (TSG), products (whereas 19 and 20 of the Regulation EU 2017/625). This legislation is globally defined as EU legislation on the agri-food supply chain (Union agri-food chain legislation) (whereas 3 of the Regulation EU 2017/625). To pursue the aforementioned purposes, the regulation also repeals the Regulation (EC) No $854 / 2004$ and other directives, together with the Council Decision 92/438/EEC (regulation on official controls; European Commission, 1992; 2004c; 2004d; 2017). The official controls should be carried out using appropriate techniques and by welltrained staff to ensure that the Competent Authorities make uniform decisions (whereas 12 of the Regulation (EC) No $882 / 04)$. The official controls should be regularly carried out with a frequency commensurate with the level of risk involved, but they can also be carried out when there is a suspicion of non-compliance (whereas 13 and 14 of the Regulation (EC) No 882/04, European Commission, 2004d). Also in the Regulation (EU) 2017/625 (Article 12) the concept is reiterated that Competent Authorities shall perform official controls in accordance with documented procedures (European Commission, 2017). In the event that non-compliance with the law is observed, the Competent Authorities [...] shall take (a) any action necessary to determine the origin and extent of the noncompliance and to establish the operator's responsibilities and (b) appropriate measures to ensure that the operator concerned remedies the non-compliance and prevents further occurrences of such noncompliance (Article 138 of the Regulation EU 2017/625, European Commission, 2017).
Correspondence: Alfredo Rossi, Local Health Authority of Benevento, Italy.

Tel.: +39.0824.308337; Fax: +39.0824.308337

E-mail: alfredo.rossi@aslbenevento1.it

Key words: Food safety, Competent Authority, Non-compliance.

Contributions: All the authors contributed equally.

Conflict of interests: the authors declare no potential conflict of interests.

Funding: None.

Received for publication: 6 October 2019.

Revision received: 25 January 2020.

Accepted for publication: 4 February 2020.

This work is licensed under a Creative Commons Attribution-NonCommercial 4.0 International License (CC BY-NC 4.0).

(C) Copyright: the Author(s), 2020

Licensee PAGEPress, Italy

Italian Journal of Food Safety 2020; 9:8607 doi:10.4081/ijfs.2020.8607

\section{Competent Authorities}

Regulation (EU) 2017/625 establishes that the official activities are performed by the Competent Authorities. The Italian Legislative Decree No 193 of November 6, 2007 (Italian Republic, 2007) identifies, among other things, the Italian Public Administration bodies assuming the role of Competent Authority in matters of food safety: [...] the Ministry of Health, the Regions and the Autonomous Provinces of Trento and Bolzano and the Local Health Authority, within their respective competences.

The above Decree established three levels of competency (i.e. central, regional and local). Designating Local Health Authority as Competent Authorities, grants those agencies the following powers: i) The ability to issue enforcement measures in the event of non-compliance with the law (Article 138 of the Regulation EU 2017/625). In fact, according to the present Italian regulation (Legislative Decree No 502/1992, Italian Republic, 1992) and subsequent amendments and supplements, the operational structure in charge of the health and hygiene protection of food is the prevention department of the Local Health Authority. For instance, depending on the nature of competence required, the Veterinary Public Health Area and the Food Hygiene and Nutrition Service are both Competent Authorities at the local level. 
Each of these structures has technicalfunctional and organizational autonomy (Article 7-quater, paragraph 4 of Legislative Decree No 502/1992), which is exercised according to regional regulations (Article 4, paragraph 2 of Legislative Decree No $165 / 2001$, Italian Republic, 2001) and subsequent amendments and supplements. In this regard, Article 8 of the Regulation (EC) No 882/2004 (on official controls performed to ensure the verification of compliance with feed and food law, animal health and animal welfare rules) establishes that official controls shall be performed according to documented procedures, including the decisions and official activities to be performed (Annex II, Chapter II, European Commission, 2004d). In fulfilment of this requirement, most of the Italian Regions have issued regulatory acts that identify duties, and responsibilities and measures to be adopted by staff and managers. The medical staff (veterinary and medical managers) is responsible for the official controls and is empowered ex lege to adopt authoritative deeds and provisions. In particular situations, the above described empowerment in is also granted to nonmanagerial personnel (prevention technicians) (Cf. Article 4, paragraph 3 of Legislative Decree No 165/2001 and subsequent amendments and supplements, Italian Republic, 2001); ii) The official controls on food safety are unequivocally assigned to the competence of the Local Health Authorities in charge of the sanitary protection of food. However, other administrations, such as the Ministry of Agriculture, Food and Forestry, still exercise controls on very specific subjects or sectors, as traceability. It is worth emphasizing that all the food legislation referring to Regulation (EC) No 178/2002 (which sets out the general principles and requirements of food law, procedures in matters of food safety, and establishes the European Food Safety Authority, EFSA) has a health purpose. Official controls by the Competent Health Authorities may also apply to some closely related aspects such as food labelling and consumer information (European Commission, 2002).

The Regulation still allows for the anomaly of Italian police performing control services (e.g. the Italian police protecting health - Carabinieri per la tutela della salute, Nuclei Antisofisticazione e Sanità (NAS). However, even though the police can perform official controls in matters governed by Regulation (EU) 2017/625, they cannot adopt administrative measures in the case of detected non-compliance (Article 138 of the Regulation (EU) 2017/625) and also, notwithstanding the provisions of Article 4 of the Regulation (EC) No 882/2004, they are excluded from system audits «Piano Nazionale Integrato (PNI) 2015-2018» as stated in the State Regions Agreement, December 18th, 2014 (Rep. Acts 177/CSR of 18/12/2014, Italian Republic, 2014; European Commission, 2004d; 2017).

\section{Non-compliance and risk assess- ment}

Therefore, when the control activity, aimed at verifying compliance with food legislation, a non-compliance should be considered any deviation from what is required by the law as detected during the control activity performed according to the methods and techniques defined by the regulations (Articles 8 and 10 of Regulation (EC) No 882/2004).

Many aspects of food safety can be subjected to official control, and noncompliance: i) foods (raw materials, ingredients, additives and adjuvants, semifinished products, contact materials, etc.); ii) establishments (structural, plant, contact materials, etc.); iii) management (procedures and application methods concerning: good manufacturing practices, good hygiene practices, hazard analysis and critical control points, weed control, etc.). Non-compliance may be detected during an inspection, an audit, or a sampling, etc. Various methods and techniques may trigger a noncompliance finding. Such methods include visual or, documentary inspections, and analytical, and instrumental audits. The evaluation of the non-compliance is of fundamental importance: such evaluation must enable the correct identification of all the potential risks and the degree of possible danger that may derive from a given food product. The evaluation process can involve the examination of a whole series of factors that are decisive in establishing the impact on a hygienic production process. Finally, it is of particular importance the evaluation of the adequacy of the self-control procedures adopted by the company, which in relation to specific production processes can be particularly demanding. Even in these cases, non-compliance may emerge, which should be addressed carefully. Indeed, the controlling authority is called upon to act appropriately against the food business operator in cases of non-compliance. The Court of Justice of the EU has expressed its opinion regarding the risk of contamination of bread for sale at a self-service without protective coverings [...] without considering the measures taken by those operators under Article 5 of the Regulation
(No 852/2004) in order to prevent, eliminate or reduce to acceptable levels the hazard which the contamination referred to in paragraph 3 of Chapter IX of Annex II to the regulation may present and without determining that the measures taken in that regard were insufficient in the light of all the available relevant data, (Case C-382/10, judgment of the court, Section Eighth, 6 October 2011, point 22). As far as food is concerned, the concepts of food risk (injurious or unfit) shall be taken into account in accordance with Article 14 of the Regulation (EC) No 178/2002. In addition, the concepts of hazard and immediate hazard for public health must also be taken into account, further to the provisions dictated by the EU and the Italian national legislation, when not in conflict with the EU provisions (European Commission, 2002). Finally, the documented procedures will be of help to the personnel performing the checks, which they must follow such procedures and must be produced by the Competent Authorities, according to their respective competences. The food business operator is free to choose the corrective actions to adopt in order to remedy the noncompliance, always keeping in mind the need to protect public health. The Supervisory Authority is responsible for assessing the adequacy and effectiveness of the corrective action.

\section{Actions in the event of non-com- pliance with the law}

Articles 137 and 138 of the Regulation (EU) 2017/625 dictate the provisions relating to suspected or ascertained noncompliance with the law. In cases of suspected or ascertained non-compliance, the Competent Authorities give priority to the actions to be taken to eliminate or to contain the risks for human health, animal health, animal welfare and with regards to GMOs (Genetically Modified Organisms) phytosanitary products, plant products, and the environment (Article 137, paragraph 1; European Commission, 2017). According to Article 54, paragraph 1 of the Regulation (EC) No 882/2004: [...] the competent authority identifies non-compliance, it shall take action to ensure that the operator remedies the situation (European Commission, 2004d). The Regulation (EU) $2017 / 625$ is expressed in the same way in Article 138, which however also charges the Competent Authorities with undertaking [...] any action necessary to determine the origin and extent of the non-compliance and to establish the operator's responsibilities, 
specifying that the Competent Authorities shall take [...] appropriate measures to ensure that the operator concerned remedies the non-compliance and prevents further occurrences of such non-compliance (European Commission, 2017). The legislator places emphasis on the possible etiological and/or epidemiological investigations (the origin and the extent of the non-compliance) and on the corrective measures to be taken by the food business operator. Measures to be taken in cases of non-compliance should emphasize preventative purposes. The new regulation also introduces etiological and/or epidemiological investigations in connection with a plant and animal health. When a Competent Authority detect a noncompliance, it has a legal obligation to take actions against the food business operator so that the latter resolves such non-compliance. The Control Authority, must ensure that the food business operator remedies the situation of non-compliance, regardless of whether the detected non-compliance represents is illicit (administrative offense). The Competent Authority will always ask the food business operator to remedy the noncompliance and stipulate an appropriate amount of time to resolve it. The food business operator will then be audited following the stipulated amount of time to assess the adequacy of the remedial action taken. It must be emphasized that these prescriptive measures, issued in accordance with Article 138, paragraph 2, should always be adopted, even in cases where Article 6 of the Italian Legislative Decree No 193/2007 does not require them (Italian Republic, 2007). As a matter of fact, under the sanctioning profile, as described by the aforementioned Article 6, there are illegal acts that are immediately sanctioned and illicit actions that may be sanctioned only if the food business operator does not eliminate the non-compliance within the proposed time limit. Article 138, paragraph 1 of the regulation establishes the evaluation criteria useful for the self-adoption of the measures that the Competent Authority will implement in the specific case and that essentially refer to two parameters: the nature of that noncompliance and the operator's past record with regard to compliance (European Commission, 2017). The correct application of these factors entails conforming to the general principles of food legislation laid down in Chapter II, Section I of the Regulation (EC) No 178/2002, which provides that the ultimate purpose of the regulation is to pursue a high level of protection of human health (European Commission, 2002).

Therefore, the control body should take into account: i) The nature of the noncompliance, i.e. the type of non-compliance, which may involve the food directly, an aspect of the productive activity, as described directly or indirectly by the regulations, and the performance of a risk assessment of the non-compliance, which evaluates the severity of non-compliance; ii) The history of the food business operator, as demonstrated by the historical data concerning that operator, having regard to its prior, non-compliances.

In this sense, both the eventual reiteration of the food business operator in terms of [...] non-compliance, whether specific or not, and more generally of the capacity and attitude assumed by the food business operator, in managing the noncompliance, as well as the seriousness of these (Cf. Note of the Ministry of Health DSPVNSA - No 20151/P of 24 May 2006, paragraph 2; Rossi A., Alimenta, 3/2009, Italian Republic, 2006). The audit by the Competent Authority may result in one of the following measures: an order, a prescriptive measure, or a protective measure. According to of Article 138, paragraph 2, the Competent Authorities shall take appropriate measures to ensure that the operator concerned remedies the noncompliance (European Commission, 2017).

The following is a list of eleven official actions, each of a peremptory nature, except in the cases of recall, withdrawal and/or destruction of goods, closing activity, suspension or withdrawal of registration/recognition, other than those specified in Article 54 of the Regulation (EC) 882/2004 (European Commission, 2004d). It is a list of mere examples; this list does not limit the possibilities for intervention by the Competent Authority.

\section{Criteria for the adoption of measures}

The administrative measures issued by the Competent Authority are generally intended to modify the production processes of the recipients. The act is legitimate, if it complies with all the elements and requirements prescribed by that particular type of act; otherwise, the act may be null or annulled. Annulment of an act implies wrongdoing by the official who issued it, and such official will be subject to legal consequences. Violations of the law, incompetence and abuse of power should not affect the issuing of measures. Abuse of power refers to the power exercised by the Authority and therefore to its activity. The measures taken by the Health Authority are mainly discretionary and may results from the misuse of power. Assessment of the measures to be taken should consider of fundamental importance, the general principles of administrative activity as dictated by the Constitution (Article 97) and by law No 241/1990 on administrative procedures, in addition to compliance with the principle of legality (Italian Republic, 1947; 1990). The principles include reasonableness, which derives from the constitutional maxims of impartiality and good performance. This principle emphasizes that the work of the Public Administration must be immune to logical complaints, adhere to factual data, and act in the public interest. This principle is to be understood through the following lenses: congruity between the normative discipline and the administrative decision, coherence between the completed evaluation and the decision taken, and coherence between comparable decisions. Due to the principle of reasonableness, administrative acts must not go beyond what is appropriate and necessary to achieve the set goals. Consequently, the provision issued by the Public Administration, with reference to the specific case, must be proportionate to the goal that must be achieved, taking into account the interests involved and the factual circumstances or evidence. Given the above principle of proportionality, another aspect of the principle of reasonableness, or rather of non-arbitrariness of the choices of the Administration, is that of impartiality or prohibition of discrimination. The principle of proportionality is the result of the case law of the European Court of Justice, which drew from the German legal system. Based on this principle, individual situations of a private nature (that is, pertaining to specific subjects) and, generally, with patrimonial content, must not be sacrificed beyond what is strictly necessary to protect the public interest. The EU therefore places fundamental importance on the principle of proportionality, which recognizes the need for and provides unequivocal protections to European citizens when faced with otherwise subjective legal situations. Upon closer consideration, the principle of proportionality can be considered an extension of the principle of legality: it is a principle of justice as it imposes on the Authority a requirement to further the public interest, through the least onerous means for citizens and businesses. The principle of proportionality has had significant impact at the national legal system level; it now has the status of a general principle, extending beyond matters of Community importance (so-called spill over effect). 


\section{Food law and the principle of proportionality}

Regulation (EC) No 178/2002 which establishes the principles and general requirements of food legislation, establishes EFSA and procedures in the field of food safety, the so-called general food law, about the measures or the other interventions for the protection of health, consequent to the assessment, management and risk assessment, states that these should be effective, proportionate and targeted measures (whereas 17 of the Regulation EC No 178/2002, European Commission, 2002). The principle of proportionality also informs of the precautionary principle (Article 7 of the Regulation EC No 178/2002) where: Measures adopted on the basis of paragraph 1 shall be proportionate and no more restrictive of trade than is required to achieve the high level of health protection [...].

In Article 17, about the measures and penalties to be applied in case of violation of food and feed legislation, the provision reiterates that these must be effective, proportionate and dissuasive. In particular, the principle of proportionality is taken from Regulation (EC) No 882/2004, where explicit reference is made to violations of food and feed law that (European Commission, 2004d): [...] should therefore be subject to effective, dissuasive and proportionate measures to national level throughout the Community (European Commission, DGSANCO and document 21/12/2005: Guidelines on the application of some provisions of the Regulation (EC) No 852/2004, European Commission, 2005).

\section{Analysis of administrative jurisprudence}

The measures adopted by the Authority pursuant to Article 54 of the Regulation (EC) No $882 / 2004$ have been the subject of appeals by food companies. In the present paper 30 sentences, issued from 2012 to June 2019 by the Regional Administrative Courts (TAR, Tribunale Amministrativo Regionale) and a ruling by the Council of State, pertaining to food safety issue were examined. The decisions of the administrative authority in the food safety sector are closely linked to a technical risk assessment, and therefore are mainly discretionary choices. The administrative judge should make a judgement on the correct exercise of the discretionary power. The study reports the cases taken into consideration according to the type of measures referred to in Article 54 of the Regulation (EC) No 882/2004 (European Commission, 2004d).

\section{Closure or suspension of the activi-} ty: Article 54, paragraph 2, letter e and/or revocation of the registration activity pursuant to Article 6 of the Regulation (EC) No 852/2004 of the Regulation (EC) (Article 54, paragraph 2, letter $h$ )

The TAR of Calabria, with the sentence No 431/2012, accepted an appeal against the provision for the revocation of the registration of a canteen activity line in a catering business, stating that the detailed regulations referred to which govern the subject of food safety are clearly inspired by the principle of proportionality of a Community nature which assumes a fundamental and innovative role in the administrative procedure since it offers greater protection for private interests. Based on this principle, the means used by the public administration must at the same time be suitable and effective for the purpose pursued. According to the statement the Local Health Authority instead of taking measures aimed at removing the anomalies found, immediately proceeded to inflict the extreme measure envisaged by the sector legislation, or the revocation and cancellation of the registration, in disregard of the principle of proportionality that the law prescribes to the administration.

Therefore, the violation of the principle of proportionality often appears as the main reason for the excess of power questioned by the judges to the Local Health Authorities, especially when the authority adopts measures that inhibit the activity of the food business operator. Other eight cases were examined; in these the TAR (Campania, Puglia, Sardinia, Sicily) accepted the appeals against the measures. The Authorities imposed extreme measures against the food companies, as the closure or suspension of the activity. The Local Health Authorities, instead of prescribing the resolution of the non-compliance highlighted (pursuant to Legislative Decree No 193/2007), they ordered the closure sine die of the catering activities (TAR Campania, sentence No 2026/2013; TAR Campania, sentence No 1716/2013, TAR Campania, sentence No 210/2014; TAR Puglia, sentence No 1178/2014; TAR Sardinia, sentence No 262/2015, sale of fish products; TAR Campania, sentence No 2047/2012, production and packaging of eggs; TAR Sicily, sentence No 1065/2014).

In other cases, the closure measures were based on violations of non-health related issue as i) occupational safety (Legislative
Decree No 81/2008, Italian Republic, 2008): TAR Campania, sentence No 2044/2019; TAR Lazio, sentence No 7069/2014; ii) building material: immediate closure of a restaurant, as the chimney had been installed without the condominium's consent (TAR Calabria, sentence No 2055/2014); iii) violation of urban planning legislation (TAR Puglia, sentence No 1806/2012); iv) lack of a certificate of practicability, an unsuccessful appeal (TAR Umbria, sentence No 143/2014). In another case the suspension of the catering for deficient intake of the fumes and harm to the neighbourhood. Act then lifted in self-defense because the local health authority in the inspection report had not been given such non-compliance. The TAR declared the matter of the dispute ceased (TAR Liguria, section I, sentence No 722/2007). The appeals were accepted if closure was ordered in the absence of health notification to the establishment. The measure adopted became a sanction which is not provided for by Legislative Decree No 193/2007 (TAR Calabria, sentence No $37 / 2015$ ), or the discrepancies which the decree indicates were not the discrepancies found, or whether or not they could be remedied as required by the municipal regulatory regulations (No 212/CSR of 10/11/2016, TAR Abruzzo, sentence No 292/2017, Italian Republic, 2016; 2017).

There were seven rejected appeals regarding the closure or suspension of the activity: in almost all cases, the motivation was linked to the lack of health and hygiene requirements (TAR Lazio, sentence No 10754/2014; TAR Campania, sentence No 471/2018; TAR Calabria, sentence No 1309/2019). In one case there was also a lack of registration; the provision was issued by the CC NAS of Caserta, rather than from the Local Health Authority, a circumstance which was not contested by the appellant (TAR Campania, sentence No 765/2018). Finally, in one case the reason was erroneous (TAR Calabria, sentence No 1118/2019).

Only one case arrived at the Council of State, concerning the decision of immediate suspension of the sale of loose bread without protective covering, but with a dedicated area. In this specific case the company was accused of not taking the necessary precautions to guarantee the bread. The Council in rejecting the appeal, also recalling the judgment of the European Court of Justice No 382/2011, carried out a broad examination of the food legislation and in particular of the obligations of the food industry operators to put in place procedures foreseen by the Article 5 of Regulation (EC) No 852/2004, aimed at ensuring food safety (European Commission, 2004a). Furthermore, according to the judges, the 
Local Health Authority had adequately motivated the inadequacy of the marketing techniques of bread (Council of State, sentence No 5714/2015; TAR Veneto, sentence No 582/2013).

The rejected appeals in the case of the closure of a bar business was due to the lack of registration (the file presented had not been approved by the One-stop Shop for Production Activities), and the requirements of ventilation in the bathroom and the necessity of another bathroom for the staff (TAR Puglia, sentence No 759/2017). In other cases, the reason was the lack of the authorization title and of the Hazard Analysis and Critical Control Points (HACCP) plan (TAR Sicily, sentence No 1852/2018).

\section{Recall and withdrawal and/or destruction of feed or food: Article 54, paragraph 2, letter c of Regulation (EC) No 882/2004}

A measure of recall and withdrawal of milk and seizure of the derived cheese was imposed on the Consortium that sold them, as the milk had a content in somatic cells and a bacterial load exceeding the limits. The court asserted that, the ruling was unjustified and in clear disregard of the provisions of the law. The Local Health Authority had qualified the milk as unfit for human consumption instead of complying with the regulatory requirements of Regulation (EC) No 853/2004, Annex III, section IX, chapter I, paragraph III, point 3 , letter a, and by the CSR 20/3/2008, Chapter II, paragraph 2 (European Commission, 2004b). The Authorities should have adopted measures that would have enabled the milk of the Consortium to re-enter the parameters dictated by the legislation towards the breeders. The Authorities acted illegitimately against the Consortium. The judge accepted the appeal and sentenced the local health authority to pay damages for the seizure immediately, due to the unlawfulness of the action (TAR Friuli Venezia Giulia, sentence No 537/2016).

The provision was made prohibiting the placing on the market of dairy products as well as seizure (pursuant to Article 20 of Presidential Decree No 327/80; Italian Republic, 1980) and destruction of cheeses produced with milk from Alpine dairies lacking both registration and necessary hygiene requirements health. The plaintiff disputed the provision of the Authority both because no analysis had been carried out on the cheese, on the assumption that the criminal state (pronunciation, however, not yet resigned) had excluded the bad state of preservation and that no danger ascertained for public health. The TAR, rejected the appeal, motivating that the Local Health Authority correctly applied the principle of precaution or of prevention (Article 7 of the Regulation (EC) No 178/2002) (European Commission, 2002): [...] in consideration of the ascertained inadequate hygienic and sanitary conditions of the mountain pastures (non-disclosure agreement: cheese factory), such as to cause potential dangers to the health of consumers, so that it is irrelevant that checks have not been carried out on the forms of Fontina covered by the disputed orders, and that: in the case of species the bad conditions of the transformations as described are certainly such as to give rise to more than a doubt in order not only to the quality, but above all to the safety of the products covered by the provision that concerns us.

The judge censured, however, for obvious illogicality the part of the provision of the Local Health Authority that limited: the scope of consumption of the products to the only family nucleus of the members [...], (TAR Valle D'Aosta, sentence No 53/2018). On the subject, it is worth mentioning the interpretation of the EU Commission where it believes: [...] that every decision must be preceded by an examination of all the available scientific data and, if possible, a risk evaluation that is as objective and comprehensive as possible. A decision to invoke the precautionary principle does not mean that the measures will be adopted on an arbitrary or discriminatory basis (Communication from the Commission on the precautionary principle - 02/02/2000 COM 2000; European Commission, 2000).

Furthermore, it should be noted that due to the seizure carried out pursuant to Article 20 of the decree of the President of the Republic No 327/80, a rule still in force as it is not in contrast with the EU legislation (Italian Republic, 1980): [...] the health authority orders the release of the goods that has been found to comply with current regulations. Otherwise, the Health Authority ascertains the edibility, making use, where necessary, for further specific laboratory investigations.

\section{Requirements and other provisions: Article 54, paragraph 2, letter h of Regulation (EC) No 882/2004}

There was an appeal accepted for the provision to impose the construction of a flue instead of a fume abatement construction with a filter with activated carbon installed by the applicant. The provision was found to be an act of abuse of power for the lack of objective, legal conditions and lack of preliminary investigation (TAR Campania, sentence No 504/2019). A second appeal was accepted for the prescriptive provision for a second toilet for the public service already authorized for many years. The provision was found to be excessive and disproportionate (TAR Marche, sentence No 60/2017). A third appeal was rejected in the case of a verification at a food distribution company resulting in a non-compliance with the traceability procedures, where the Local Health Authority found no correlation of lots on the invoices from supplier or in another format; this is in violation to Regulation (EU) No 931/2011 for food of animal origin (European Commission, 2011). The exegetical analysis of the applicable discipline carried out by the judge is of particular interest when particular attention was paid to the purpose of the community regulation. The Authority - according to the judge - in considering this information "appropriate" (Article 3, point 1, letter g of the Regulation (EU) No 931/2011, European Commission, 2011) prescribed the company to adopt, within 30 days, an appropriate system of transmission of information (lot), without however predetermining it. In doing so, the Authority guaranteed the principle of proportionality. The appeal was rejected (TAR Calabria, sentence No 88/2019).

There was a provision of the Local Health Authority against a cooking center that had agreed to maintain a limit of 500 daily meals, as well as to fulfil other prescriptions within a period of time. The assessment was explicitly evaluated on the basis of the type of activity, the structural dimensions, the equipment and the personnel employed, the procedures adopted, the operating procedures, were deemed not to justify the declared expansion of the production capacity (numerous critical points in terms of operational spaces, the availability of accessory environments and incidents on the performance of production cycles). It should be noted that during the preliminary investigation the report presented by the plaintiff company did not give an account of the actual ability of the cooking center to produce a higher number of meals, this does not influence the overall evaluation of the public service company, and has mainly discretionary content. With respect to the decision of the local healthcare company, the judge observed that there are no fixed parameters established by the current legislation, to which reference can be made to measure the productive capacity of cooking centers; but above all that this capacity is, at least in part, influenced by the type of meals to be prepared and by the specific context in which this activity is carried out. The Competent Authority in the evaluation would then have followed the regional guidelines which urge to consider 
risk analysis, the ergonomic and functional organization of the plants. The appeal was rejected (TAR Sicily, sentence No 719/2016). A different appeal was accepted for the provision against a food business operator, requesting the issue of health certification for goods destined for export to non-EU countries. The requirement of sampling by personnel of the local health authority and transfer of samples to laboratories of the agency's regional environmental protection, according to the court, the measure burdened by the official control would end up replacing or rendering useless the self-control accepted by the community legislation. Besides, and again that"the clear proof of the disproportion of the procedure imposed on the applicant occurs if we consider that the official controls on foodstuffs intended for exports to non-EU countries must be carried out with the same accuracy as those required for distribution in the domestic and national market (Article 3, paragraph 4 of Regulation (EC) No 882/2004, European Commission, 2004d; TAR Puglia, section II, sentence No 1342/2017).

\section{Conclusions}

The final measure issued by the Competent Authority represents the decisive moment of the official control activity. The measures should be issued by carrying out a correct assessment of the risk connected to the case at hand and in compliance with the general legal principles that support official administrative activities. The analysis of cases scrutinized by the administrative judiciary, reveals a general criticism of the work of the local Competent Authorities, especially where the extreme measure of closure of the activity was applied. The case law emphasizes the widespread incorrect application of the legislation on food hygiene, and the violation of the principle of proportionality, which ought to regulate the wide discretion of the authority. From a technical and hygienic point of view, except for very few cases, the assessment of noncompliance - mainly of a structural natureand therefore the related risk assessment, does not appear to be fully carried out by the control body. However, it is not such as to fully justify the most serious measures adopted. Finally, with regard to registration, pursuant to Article 6 of the Regulation (EC) No 852/2004 (European Commission, 2004a), from a legal point of view, an assimilation to the notion of authorization is noted, which is a significant instead of departure from the national implementing regulations.

\section{References}

Case C-382/10, judgment of the court (Section Eighth) 6 October 2011, point 22. web: curia.europa.eu.

Council of State, sentence No 5714/2015. web: www.giustiziamministrativa.it.

European Commission, 1992. Council Decision of 13 July 1992 on computerization of veterinary import procedures, amending Directives 90/675/EEC, 91/496/EEC, 91/628/EEC and Decision 90/424/EEC, and repealing Decision 88/192/EEC. In: Official Journal, L 243/28, 25/80/1992.

European Commission, 2000. Communication from the commission on the precautionary principle. In: Commission of the European Communities, 2/2/2000 COM (2000).

European Commission, 2002. Regulation of the European Parliament and of the Council of 28 January 2002, laying down the general principles and requirements of food law, establishing the European Food Safety Authority and laying down procedures in matters of food safety, 178/2002 EC. OJ L 31.

European Commission, 2004a. Regulation of the European Parliament and of the Council of 29 April 2004, on the hygiene of foodstuffs, 852/2004 EC. OJ L 139.

European Commission, 2004b. Regulation of the European Parliament and of the Council of 29 April 2004, laying down specific hygiene rules for food of animal origin, 853/2004 EC. OJ L 139.

European Commission, 2004c. Regulation of the European Parliament and of the Council of 29 April 2004, laying down specific rules for the organization of official controls on products of animal origin intended for human consumption, 854/2004 EC. OJ L 155.

European Commission, 2004d. Regulation of the European Parliament and of the Council of 29 April 2004, on official controls performed to ensure the verification of compliance with feed and food law, animal health and animal welfare rules, 882/2004 EC. OJ L 165.

European Commission, 2005. Guidelines on the application of some provisions of the Regulation (EC) No 852/2004. In: European Commission, DGSANCO and document 21/12/2005.

European Commission, 2011. Regulations commission implementing regulation (EU) No $931 / 2011$ of 19 September 2011 on the traceability requirements set by Regulation (EC) No 178/2002 of the European Parliament and of the Council for food of animal origin. OJ L 242.

European Commission, 2017. Regulation of the European Parliament and of the Council of 15 march 2017, on official controls and other official activities performed to ensure the application of food and feed law, rules on animal health and welfare, plant health and plant protection products, amending Regulations (EC) No 999/2001, (EC) No 396/2005, (EC) No 1069/2009, (EC) No 1107/2009, (EU) No 1151/2012, (EU) No 652/2014, (EU) 2016/429 and (EU) 2016/2031 of the European Parliament and of the Council, Council Regulations (EC) No 1/2005 and (EC) No 1099/2009 and Council Directives 98/58/EC, 1999/74/EC, 2007/43/EC, 2008/119/EC and $2008 / 120 / \mathrm{EC}$, and repealing Regulations (EC) No 854/2004 and (EC) No $882 / 2004$ of the European Parliament and of the Council, Council Directives 89/608/EEC, 89/662/EEC, 90/425/EEC, 91/496/EEC, 96/23/EC, 96/93/EC and 97/78/ EC and Council Decision 92/438/EEC (Official Controls Regulation), 2017/625 EU. OJ L 95.

European Court of Justice No 382/2011.web: curia.europa.eu.

Italian Republic, 1947. Costituzione della Repubblica italiana 27 dicembre 1947. OF L 298.

Italian Republic, 1980. Decreto del Presidente della Repubblica 26 marzo 1980, n. 327. Regolamento di esecuzione della L. 30 aprile 1962, n. 283, e successive modificazioni, in materia di disciplina igienica della produzione e della vendita delle sostanze alimentari e delle bevande. OJ L 193.

Italian Republic, 1990. Legge 7 agosto 1990, n. 241. Nuove norme in materia di procedimento amministrativo e di diritto di accesso ai documenti amministrativi. OJ L 192.

Italian Republic, 1992. Decreto Legislativo 30 dicembre 1992, n. 502. Riordino della disciplina in materia sanitaria, a norma dell'articolo 1 della legge 23 ottobre 1992, n. 421. OJ L 305.

Italian Republic, 2001. Decreto Legislativo 30 marzo 2001, n. 165. Norme generali sull'ordinamento del lavoro alle dipendenze delle amministrazioni pubbliche. OJ L 106.

Italian Republic, 2006. Nota Ministero della Salute. Indicazioni relative a taluni aspetti dei nuovi regolamenti sulla sicurezza alimentare con particolare riferimento al regolamento $\mathrm{CE}$ 882/2004. In: prot. 20151/P.

Italian Republic, 2007. Decreto Legislativo n. 193 del 06/11/2007. Attuazione della direttiva 2004/41/CE relativa ai controlli in materia di sicurezza alimentare e applicazione dei regolamenti comunitari 
nel medesimo settore. OJ L 261.

Italian Republic, 2008. CSR 20/3/2008. Conferenza permanente per i rapporti tra lo stato le regioni e le province autonome di Trento e Bolzano. Intesa, ai sensi dell'articolo 8, comma 6, della legge 5 giugno 2003, n. 131, tra il Governo, le Regioni e le Province autonome di Trento e di Bolzano sul documento recante «Linee guida per l'esecuzione dei controlli tesi a garantire la sicurezza alimentare nell' ambito della produzione e immissione sul mercato del latte destinato al trattamento termico e alla trasformazione». OJ L133 Rep. atti n. 103/CSR.

Italian Republic, 2008. Decreto Legislativo 9 aprile 2008, n. 81. Attuazione dell'articolo 1 della legge 3 agosto 2007, n. 123 , in materia di tutela della salute e della sicurezza nei luoghi di lavoro. OJ L 101.

Italian Republic, 2012. Tribunale Amministrativo Regionale Calabria, sentence No 431/2012. web: www.giustiziamministrativa.it.

Italian Republic, 2012. Tribunale Amministrativo Regionale Campania, sentence No 2047/2012. web: www.giustiziamministrativa.it.

Italian Republic, 2012. Tribunale Amministrativo Regionale Puglia, sentence No 1806/2012. web: www.giustiziamministrativa.it.

Italian Republic, 2013. Tribunale Amministrativo Regionale Campania, sentence No 2026/2013. web: www.giustiziamministrativa.it.

Italian Republic, 2013. Tribunale Amministrativo Regionale Campania, sentence No 1716/2013. web: www.giustiziamministrativa.it.

Italian Republic, 2013. Tribunale Amministrativo Regionale Veneto, sentence No 582/2013. web: www.giustiziamministrativa.it.

Italian Republic, 2014. Piano Nazionale Integrato (PNI) 2015-2018 di cui all'Intesa Stato Regioni del 18 dicembre 2014. In: Rep. Atti 177/CSR, 18/12/2014.

Italian Republic, 2014. Tribunale Amministrativo Regionale Calabria, sentence No 2055/2014. web: www.giustiziamministrativa.it.

Italian Republic, 2014. Tribunale Amministrativo Regionale Campania, sentence 210/2014. web: www.giustiziamministrativa.it.

Italian Republic, 2014. Tribunale Amministrativo Regionale Lazio, sentence No 10754/2014. web: www.giustiziamministrativa.it.

Italian Republic, 2014. Tribunale Amministrativo Regionale Lazio, sentence No 7069/2014. web: www.giustiziamministrativa.it.

Italian Republic, 2014. Tribunale Amministrativo Regionale Puglia, sentence No 1178/2014. web: www.giustiziamministrativa.it.

Italian Republic, 2014. Tribunale Amministrativo Regionale Sicily, sentence No 1065/2014. web: www.giustiziamministrativa.it.

Italian Republic, 2014. Tribunale Amministrativo Regionale Umbria, sentence No 143/2014. web: www.giustiziamministrativa.it.

Italian Republic, 2015. Tribunale Amministrativo Regionale Calabria, sentence No 37/2015. web: www.giustiziamministrativa.it.

Italian Republic, 2015. Tribunale Amministrativo Regionale Sardinia, sentence No 262/2015. web: www.giustiziamministrativa.it.

Italian Republic, 2016. Conferenza StatoRegioni. Intesa, ai sensi dell'articolo 8, comma 6, della legge 5 giugno 2003, n. 131, tra il Governo, le Regioni e le Province autonome di Trento e Bolzano sul documento concernente Linee guida per il controllo ufficiale ai sensi dei Regolamenti (CE) 882/2004 e 854/2004. Intesa, ai sensi dell'articolo 8, comma 6, della legge 5 giugno 2003, n. 131. In: Rep. Atti 212/CSR.

Italian Republic, 2016. Tribunale Amministrativo Regionale Friuli Venezia Giulia, sentence No 537/2016. web: www.giustiziamministrativa.it.

Italian Republic, 2016. Tribunale Amministrativo Regionale Sicily, sentence No 719/2016. web: www.giustiziamministrativa.it.

Italian Republic, 2017. Tribunale Amministrativo Regionale Abruzzo, sentence No 292/2017. web: www.giustiziamministrativa.it.

Italian Republic, 2017. Tribunale Amministrativo Regionale Marche, sentence No 60/2017. web: www.giustiziamministrativa.it.

Italian Republic, 2017. Tribunale Amministrativo Regionale Puglia, sentence No 759/2017. web: www.giustiziamministrativa.it.

Italian Republic, 2017. Tribunale Amministrativo Regionale Puglia, section II, sentence No 1342/2017. web: www.giustiziamministrativa.it.

Italian Republic, 2018. Tribunale Amministrativo Regionale Campania, sentence No 471/2018. web: www.giustiziamministrativa.it.

Italian Republic, 2018. Tribunale Amministrativo Regionale Campania, sentence No 765/2018. web: www.giustiziamministrativa.it.

Italian Republic, 2018. Tribunale Amministrativo Regionale Sicily, sentence No 1852/2018. web: www.giustiziamministrativa.it.

Italian Republic, 2018. Tribunale Amministrativo Regionale Valle D'Aosta, sentence No 53/2018. web: www.giustiziamministrativa.it.

Italian Republic, 2019. Tribunale Amministrativo Regionale Calabria, sentence No 1118/2019. web: www.giustiziamministrativa.it.

Italian Republic, 2019. Tribunale Amministrativo Regionale Calabria, sentence No 88/2019. web: www.giustiziamministrativa.it.

Italian Republic, 2019. Tribunale Amministrativo Regionale Calabria, sentence No 1309/2019. web: www.giustiziamministrativa.it.

Italian Republic, 2019. Tribunale Amministrativo Regionale Campania, sentence No 504/2019. web: www.giustiziamministrativa.it.

Italian Republic, 2019. Tribunale Amministrativo Regionale Campania, sentence 2044/2019. web: www.giustiziamministrativa.it.

Rossi A., 2009. I provvedimenti dell'Autorità competente ai sensi dell'art. 54 del Reg. CE n. 882/2004, Alimenta, 3: 51-58. 